\title{
PENGARUH SIKAP KERJA DAN MOTIVASI KERJA TERHADAP KINERJA KARYAWAN PT. KINANTY PATOPANG
}

\author{
A. Dirwan \\ Pascasarjana Magister Manajemen Universitas Suryadarma \\ Email:achmaddirwan@yahoo.co.id
}

\begin{abstract}
The purpose of this study was to determine the influence of work attitude and motivation on employees peformance at PT Kinanty Patopang. The subject of this research were 50 employees. By using 5 Likert Scale. The frame work of this research was based on that work attitude $\left(\mathrm{X}_{1}\right)$ and work motivation $\left(\mathrm{X}_{2}\right)$ had influence of employees performance $(Y)$. The work attitude was measured bay 30 items question, work motivation was measured bay 31 items question, and employees performance was measured with 39 items question/statement. Data analysis used in this research was a multiple regression to analyzed data. Obtained data then were examined with SPSS 17.0 version. From the research it can concluded that : (1) there was influence of work attitude toward employees performance; (2) there was influence of work motivation toward employees performance, (3) there was influence of work attitude and work motivation simultaneously toward employees performance of PT. Kinanty Patopang.
\end{abstract}

Keywords: work attitude, work motivation, performance.

\begin{abstract}
Abstrak. Tujan dari penelitian ini adalah untuk mengetahui pengaruh sikap kerja dan motivasi kerja terhadap kinerja karyawan PT Kinanty Patopang. Subjek penelitian ini adalah sebanyak 50 karyawan, dengan menggunakan 5 Skala Likert. Kerangka penelitian mengacu pada apakah sikap kerja dan motivasi kerja mempunyai pengaruh terhadap kinerja karyawan, diukur dari 30 butir pertanyaan/pernyataan untuk sikap kerja $\left(\mathrm{X}_{1}\right), 31$ butir untuk motivasi kerja $\left(\mathrm{X}_{2}\right)$, dan 39 butir untuk kinerja $(\mathrm{Y})$. Analisis data yang dipakai dalam penelitian adalah analisis regresi berganda. Hasil pengujian data diperoleh dengan menggunakan Program SPSS versi 17.0. Dari hasil penelitian dapat disimpulkan bahwa : (1) terdapat pengaruh dari sikap kerja terhadap kinerja, (2) terdapat pengaruh dari motivasi kerja terhadap kinerja, (3) terdapat pengaruh sikap kerja dan motivasi kerja secara bersama-sama terhadap kinerja karyawan PT Kinanty Patopang.
\end{abstract}

Kata kunci: sikap kerja, motivasi kerja, kinerja.

\section{PENDAHULUAN}

Era bisnis saat ini sangat dinamis dimana tingkat persaingan bisnis antar perusahaan semakin ketat, baik di pasar domestik maupun pasar internasional. Persamaan produk, fitur, atau kemudahan pelayanan membuat logistic service provider (LSP) menjadi industri jasa yang homogen. Untuk memenangkan persaingan dalam industri jasa yang homogen, salah satu cara adalah menyediakan jenis dan kualitas layanan yang bisa membedakan suatu LSP dengan provider logistik yang lain, serta membentuk customer based yang kuat. PT. Kinanty Patopang dalam proses operasinya untuk meningkatkan daya saing mempunyai beberapa tujuan, antara lain mengembangkan kualitas sumber daya 
manusia. Pengembangan kualitas tersebut salah satunya dipengaruhi oleh tinggi rendahnya kinerja pegawai. Kinerja pegawai adalah suatu konsep yang menunjukkan adanya kaitan antara hasil kerja dengan waktu yang dibutuhkan untuk menghasilkan produk dari seorang pegawai. Terdapat beberapa permasalahan yang mempengaruhi kinerja, seperti keselamatan individu, keselamatan pekerjaan, dan motivasi. Keselamatan individu terdiri dari; minat dan kebutuhan yang dibawa seseorang ke dalam motivasi kerja. Keselamatan pekerjaan adalah sifat dan tugas karyawan, diantaranya tanggung jawab, macam tugas, dan tingkat kepuasan seseorang (sikap kerja) terhadap pekerjaan. Motivasi kerja adalah faktor-faktor dalam lingkungan kerja yang mendorong seseorang untuk menyelesaikan tugas-tugasnya.

Kondisi perusahaan Indonesia yang masih sulit bersaing dengan perusahaan luar negeri, khususnya perusahaan yang bergerak di bidang jasa logistik, terindikasi memiliki permasalahan dengan regulasi pemerintah, infrastruktur jalan, ketersediaan armada, bahan bakar, dan sistem tarif. Di samping itu untuk memulihkan kondisi perusahaan diperlukan penanganan terhadap karyawan baik teknis maupun non teknis. Permasalahan nonteknis diantaranya motivasi kerja, sikap kerja dan kinerja karyawan. Kekuatan dari dalam diri seseorang yang mendorong untuk melakukan kegiatan, merupakan suatu motivasi untuk meningkatkan kinerja. Sikap kerja yang ada pada diri seseorang akan mewujudkan suatu perilaku yang diarahkan kepada pencapaian tujuan pekerjaan secara berhasil. Kinerja perusahaan akan didapat dari akumulasi kinerja semua individu yang ada di dalamnya.

Dengan penanganan yang terpadu dan kerjasama yang baik, saat ini PT. Kinanty Patopang telah menjadi perusahaan yang mempunyai daya saing tinggi. Untuk pembuktian secara empiris perlu diadakan penelitian sejauh mana pengaruh sikap kerja dan motivasi kerja terhadap kinerja (prestasi kerja) tersebut.

Tujuan penelitian ini adalah untuk mengidentifikasi variabel-variabel yang terlibat dalam penelitian. Variabel penelitian dibagi menjadi dua yaitu variabel terikat (dependent variable) dan variabel bebas (independent variable). Variabel-variabel tersebut adalah faktor sikap kerja $\left(\mathrm{X}_{1}\right)$, motivasi $\left(\mathrm{X}_{2}\right)$ sebagai variabel bebas: Sedangkan variabel terikat adalah kinerja karyawan (Y).

Kinerja. Porter dan Lawler dalam As'ad (1982: 46) menyatakan bahwa kinerja adalah "successful role achievement" yang diperoleh seseorang dari perbuatan-perbuatannya. Dari batasan tersebut jelaslah bahwa yang dimaksud dengan kinerja adalah hasil yang dicapai oleh seseorang menurut ukuran yang berlaku untuk pekerjaan yang bersangkutan. Kinerja menurut Vroom dalam As'ad (1982:47), tingkat sejauh mana keberhasilan seseorang di dalam melaksanakan tugas pekerjaannya disebut "level of performance". Biasanya orang yang level of performance-nya tinggi disebut sebagai orang yang produktif, dan sebaliknya orang yang level of performance-nya 'rendah (tidak mencapai standar) dikatakan sebagai tidak produktif.

Kriteria kinerja menurut Gomes (2006) adalah: (1) Quantity of work merupakan jumlah kerja dalam priode tertentu; (2) Quality of work merupakan kualitas kerja yang dicapai; (3) Job knowledge, luasnya pengetahuan tentang pekerjaan; (4) Creativeness yaitu keaslian gagasan dan tindakan menyelesaikan persoalan; (5) Cooperation, kesedian bekerja sama; (6) Dependability, kesadaran dalam penyelesaian kerja; (7) Initiative, semangat dan tanggung jawab melaksanakan ide dan tugas baru (8) Personal Qualities, menyangkut kualitas kepribadian. Sementara itu penilaian kinerja adalah suatu diskripsi sistematis yang berkaitan dengan kekuatan dan kelemahan individu atau kelompok 
terhadap suatu pekerjaan. Casio (1987:59) dalam konteks pengelolaan sumber daya manusia, penilaian kinerja secara formal mempunyai tujuan sebagai berikut: (1) penilaian kinerja dapat digunakan sebagai dasar pembuatan kebijakan yang berkaitan dengan ketenagakerjaan, (2) hasil penilaian dapat digunakan sebagai kriteria/standar dalam penelitian sumber daya manusia, (3) hasil penilaian dapat digunakan sebagai prediktor, (4) hasil penilaian dapat digunakan untuk menyusun program-program pelatihan, (5) hasil penilaian dapat memberikan umpan balik bagi yang dinilai, (6) hasil penilaian dapat digunakan untuk memperkirakan kondisi organisasi dan kemungkinan pengembangannya.

Agar sebuah sistem penilaian bisa berhasil maka harus dapat memenuhi dua persyaratan dasar, yaitu relevan terhadap pekerjaan yang dinilai dan dapat diterima oleh pihak yang dinilai maupun pihak penilai. Cara yang terbaik untuk melakukan hal ini adalah dengan mendasarkan sebagian penilaian kinerja pada kualitas penilaian bawahan (Cook, 1997: 223).

Sikap Kerja. Sikap menurut Robbins (2008: 104) adalah "attitudes are evaluative statements, either fovourable or unfavourable, about objects, people, or events". Wekley dan Yuki dalam As'ad (1990:44) memberikan batasan sikap kerja sebagai "the process by which behavior is energized and directed". Sikap kerja dan motivasi kerja adalah sesuatu yang menimbulkan semangat atau dorongan kerja, merupakan suatu proses psikologis yang mencerminkan interaksi antara sikap, kebutuhan, persepsi, dan keputusan yang terjadi pada diri seseorang. Sikap kerja timbul akibat faktor dalam diri seseorang yang disebut faktor intrinsik dan dari luar diri seseorang yang disebut faktor ekstrinsik.

Dengan demikian dapat didefinisikan bahwa sikap kerja adalah pernyataan evaluasi, baik yang menyenangkan maupun yang tidak menyenangkan terhadap suatu objek, orang, atau peristiwa di lingkungan kerja. Faktor-faktor dalam sikap kerja antara lain: (1) sifat pekerjaan (work itself), (2) pengawasan (supervision), (3) pembayaran gaji (pay), (4) peluang promosi (advancement opportunities), (5) rekan-rekan kerja (coworkers).

Motivasi Kerja. Robbin (1996: 205) mengemukakan bahwa prestasi, kekuasaan dan afiliasi merupakan tiga kebutuhan penting yang membantu memahami motivasi. Kebutuhan seseorang akan prestasi antara lain tercermin dari keinginan mengambil tugas yang dapat dipertanggung jawabkan dan menentukan tujuan yang wajar dengan memperhitungkan resiko-resikonya. Kebutuhan akan kekuasaan antara lain tercermin dari seseorang yang ingin mempunyai pengaruh atas orang lain disekitarnya dan membuat terkesan padanya. Kebutuhan akan afiliasi antara lain ditunjukkan adanya keinginan untuk bersahabat dan lebih senang bekerja bersama.

Definisi motivasi menurut Osborn (2007: 2) adalah nilai dan kepercayaan yang ada pada diri karyawan, yang dapat menentukan perilaku mereka dalam menjalankan tugas yang dipercayakan. Motivasi menurut Woolfolk (1995:123), adalah " $a$ high level of task commitment or motivation to achieve in certain areas". Motivasi seseorang terhadap tugas diartikan sesuai dengan konsep diatas adalah suatu dorongan khusus untuk mencapai tujuan. Hanya mereka yang memiliki dorongan dan tanggung jawab tinggi yang akan menunjukkan hasil kerja yang baik dan memiliki nilai lebih.

Kerangka Pemikiran. Penelitian Susilawati (2009), menyimpulkan kinerja pegawai merupakan hasil kerja sebagai akibat suatu tindakan seseorang dalam melaksanakan tugas dengan dilandasi oleh kemampuan, sikap, dan motivasinya. Sikap terhadap pekerjaan merupakan tedensi yang tetap mengenai perasaan dan perilaku terhadap suatu objek 
(Spector, 2006). Hal ini sering dianggap bahwa para karyawan yang menunjukkan sikap positif terhadap pekerjaannya akan melaksanakan pekerjaan dengan lebih baik. McClelland (1987) berpendapat "ada hubungan yang positif antara motivasi berprestasi dengan pencapaian prestasi kerja". Sementara itu menurut Long (2000:219), komitmen atau motivasi merupakan ikrar atau ikatan terhadap sesuatu tindakan. Dorongan internal akan mengarahkan suatu kemampuan untuk keberhasilan kerja.

Kerangka Konseptual

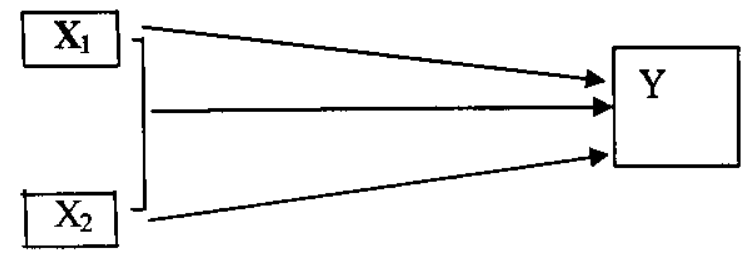

Untuk kepentingan penelitian hubungan antara Variabel Terikat dan Variabel Bebas, disimbulkan $\mathbf{X}_{\mathbf{1}}$ (sikap kerja) dan $\mathbf{X}_{\mathbf{2}}$ (motivasi kerja) sebagai variabel bebas. Sedangkan $\mathrm{Y}$ (kinerja karyawan) sebagai variabel terikat.

\section{METODE}

Pemilihan Metode Penelitian. Penelitian ini mengambil referensi kepada metode penelitian sosial yang pernah dilakukan sebelumnya (Rosete dan Ciarrochi, 2007). Metode yang digunakan dalam penelitian ini adalah correlation research yang bertujuan untuk mengetahui sejauh mana variasi-variasi pada suatu faktor berkaitan dengan variasi pada suatu atau lebih faktor lain berdasarkan koefisien korelasi. Penelitian dilakukan melalui survei, karena ingin mengungkap keadaan nyata tentang hal-hal yang dialami sampel penelitian, untuk menguji hipotesis mengenai pengaruh sikap kerja dan motivasi terhadap kinerja.

Populasi dan Sampel. Penelitian ini dilakukan di PT Kinanty Patopang Jakarta dengan sasaran penelitian seluruh karyawan. Karena jumlah karyawan tetap terbatas hanya 50 orang, selunuhnya dijadikan responden penelitian. Dipilih sampel secara acak sederhana (simple random sampling) sehingga diperoleh 20 orang untuk uji coba instrumen penelitian dan 30 orang sampel penelitian.

Instrumen Penelitian dan Pengumpulan Data. Penelitian ini menggunakan data primer. Pengukuran dilakukan pada situasi nyata yang dilihat menurut penilaian responden tentang apa yang dialami, bukan apa yang diinginkan. Instrumen pengumpulan data yang digunakan adalah angket, disusun dalam bentuk skala sikap metode likert. Skala sikap metode likert terdiri dari pernyataan-pernyataan (statements) yang disusun menyerupai tes objektif pilihan ganda. Alternatif jawaban yang disediakan dalam instrumen, dipilih jawaban dengan lima alternatif. Jawaban yang dipilih diharapkan dapat menggambarkan seberapa tinggi perasaan (affect) dan penilaian dari responden terhadap pernyataan yang disajikan dalam skala. Karena penilaian seseorang bisa "favorable" atau "unfovorable" terhadap sesuatu, maka pernyataan yang terdapat dalam skala disusun untuk menampung kedua sikap tersebut. Angket terdiri atas 3 bagian sesuai dengan jumlah variabel penelitian. Tiap-tiap variabel terdiri atas beberapa dimensi dan indikator, sebagai acuan dalam mengembangkan instrumen. Setiap butir angket berisi pernyataan-pernyataan yang ada kaitannya dengan faktor-faktor dari setiap variabel. 
Kalibrasi dan Hasil Uji Coba. Penyempurnaan instrumen dilakukan pada tahap awal sebagai uji validitas "content", melalui diskusi instrumen penelitian. Hasil diskusi telah dapat memperbaiki pernyataan-pernyataan dalam skala, sehingga mewakili "sample of bahavior to be measured" (Anastasi, 1997), dan sudah cukup relevan serta representatif. Uji coba instrumen sebagai uji empiris dilakukan pada 20 orang responden karyawan PT Kinanty Patopang Jakarta. Maksud ujicoba instrumen adalah untuk menguji kehandalan (validitas) dan kesahihan (reliabilitas) butir-butir yang akan digunakan dalam penelitian. Prosedur analisis tersebut sekaligus memberikan gambaran tentang. "internal consistency" yang didasarkan pada homogenitas butir, serta mempunyai relevansi dengan "content validity" instrument (Lewis, 1994:95). Instrumen yang diujicoba, dianalisis dengan tujuan untuk menyeleksi butir-butir yang valid, handal dan komunikatif, melalui tehnik korelasi "Product Moment" antara skor masing-masing butir dengan skor totalnya. Koefisien reliabilitas instrumen digunakan untuk melihat konsistensi jawaban yang diberikan responden, dengan menggunakan "Alpha Cronbach" (Syaifudin, 1997:5) Metoda ini dipilih dan dianggap sesuai karena instrumen disusun untuk menggali pengalaman maupun penilaian responden. Sehingga seluruh butir dianggap mengukur konsep yang sama. Dari hasil pengujian kehandalan dan kesahihan butir-butir instrumen, di pilih beberapa butir yang koefisien validitas signifikan dengan alpha $=0,05(\mathrm{r}>0,444)$, untuk digunakan sebagai instrumen penelitian, variabel kinerja karyawan diperoleh 39 butir, dengan reliabilitas sebesar 0,729 , variabel sikap kerja diperoleh 30 butir dengan reliabilitas sebesar 0,811 , variabel motivasi kerja diperoleh 31 butir dengan reliabilitas sebesar 0,863 .

Analisis Data. Untuk mengetahui hubungan antara variabel $X_{1}$ dan $X_{2}$ sebagai variabel bebas dengan variabel $\mathrm{Y}$ sebagai variabel terikat, dilakukan dengan perhitungan analisis koefisien korelasi. Analisis koefisien determinasi merupakan suatu analisis untuk mengetahui konstribusi pengaruh variabel bebas terhadap variabel terikat secara persentase. Tinggi rendahnya tingkat keeratan hubungan antar variabel penelitian dapat dilihat dari besar kecilnya nilai koefisien korelasi ( $r$ ) yang diperoleh dari hasil analisis data penelitian dengan menggunakan sofware SPSS 17.0. Analisis Regresi untuk melihat hubungan fungsional antara variabel bebas dengan variabel terikat, yang disimbulkan dengan $Y=f(X)$, dimana perubahan rata-rata harga $Y$ ditentukan oleh turun naiknya harga setiap unit $\mathrm{X}$.

\section{HASIL DAN PEMBAHASAN}

Pengujian Persyaratan Analisis. Untuk mengetahui apakah data yang akan dianalisis berdistribusi normal, digunakan uji Lilliefors, yang meliputi pengujian normalitas variabel sikap kerja $\left(\mathrm{X}_{1}\right)$, motivasi kerja $\left(\mathrm{X}_{2}\right)$, dan Kinerja $(\mathrm{Y})$, sebagai persyaratan dalam analisis regresi. Dengan menggunakan taraf signifikan $\alpha=0,05$ dan banyaknya $n=30$, didapat hasil seperti tabel 1 .

Dari tabel 1 dijelaskan bahwa untuk seluruh variabel dengan $\alpha=0,05$ diperoleh Lobservasi $<\mathrm{L}_{\text {tabel, }}$ (untuk $\mathrm{n}=30$, nilai kritis 0,161: Canover 1973) sehingga dapat disimpulkan, bahwa hasil pengujian menunjukkan sampel yang dipilih berasal dari populasi yang berdistribusi normal. Pengujian Homogenitas varians, kelompok data $Y$ didasarkan pada urutan data $\mathrm{X}_{1}$ dan $\mathrm{X}_{2}$ dengan Uji Bartlett. 
Tabel 1. Uji Normalitas (SPSS 17.0)

Tests of Normality

\begin{tabular}{ccccccc}
\hline & \multicolumn{3}{c}{ Kolmogorov-Smirnov $^{\star}$} & \multicolumn{3}{c}{ Shapiro-Wilk } \\
\hline & Statistic & $\mathrm{df}$ & Sig. & Statistic & df & Sig. \\
KINERJA & .126 & .30 & $.200^{*}$ & .967 & 30 & .457 \\
SIKAPKERJA & .104 & 30 & $.200^{\circ}$ & .980 & 30 & .819 \\
MOTIVASI & .109 & 30 & $.200^{*}$ & .982 & 30 & .868 \\
\hline
\end{tabular}

a. Lilliefors Significance Correction

*. This is a lower bound of the true significance.

Sumber: data diolah

Tabel 2. Hasil Pengujian Homogenitas Varians Populasi

\begin{tabular}{ccccccc}
\hline $\begin{array}{c}\text { Kelompok } \\
\text { Sampel }\end{array}$ & $\begin{array}{c}\text { Jumlah } \\
\text { Sampel }\end{array}$ & $\begin{array}{c}\text { Jumlah } \\
\text { Kelompok }\end{array}$ & $\mathrm{Dk}$ & $\mathrm{X}_{\text {hitung }}^{2}$ & $\begin{array}{c}\mathrm{X}_{\text {tabel }}^{2} \\
\alpha=0,05\end{array}$ & Kesimpulan \\
\hline $\mathrm{X}_{1}$ & 30 & 9 & 8 & 6,79 & 15,5 & Homogen \\
$\mathrm{X}_{2}$ & 30 & 8 & 7 & 5,48 & 14,1 & Homogen \\
\hline
\end{tabular}

Sumber: data diolah

Dari tabel di atas ternyata harga setiap $\mathbf{X}^{2}$ hitung lebih kecil dari harga $\mathbf{X}^{2}$ tabel , artinya varians kelompok-kelompok $\mathrm{X}_{1}$ dan $\mathrm{X}_{2}$ terhadap $\mathrm{Y}$ adalah homogen.

Analisis Regresi dan Korelasi. Dari hasil analisis regresi sederhana $\mathrm{Y}$ atas $\mathrm{X}_{1}$ diperoleh persamaan regresi $\hat{\mathrm{Y}}=63,15+0,709 \mathrm{X}_{1}$. Secara keseluruhan pengujian signifikansi hubungan antara sikap kerja terhadap kinerja, digambarkan dalam tabel berikut.

Tabel 3. Analisis Varians Regresi $Y$ atas $X_{1}$ dengan model regresi

$$
\hat{Y}=63,15+0,709 X_{1}
$$

\begin{tabular}{ccccccc}
\multicolumn{8}{c}{ ANOVA $^{\mathbf{b}}$} \\
\hline & Model & Sum of Squares & Df & Mean Square & F & Sig. \\
\hline 1 & Regression & 977.745 & 1 & 977.745 & 34.289 & $.000^{\mathbf{a}}$ \\
& Residual & 798.422 & 28 & 28.515 & & \\
& Total & 1776.167 & 29 & & & \\
\hline
\end{tabular}

a. Predictors: (Constant), SIKAPKERJA

b. Dependent Variable: KINERJA

Sumber: data diolah

Pada tabel 4 dijelaskan, terbukti bahwa uji regresi $\mathbf{F}_{\text {hitung }}=34,29$ lebih besar dari $\mathbf{F}_{\text {tabel(1/28:0,05) }}=4,20$ dan uji linieritas $\mathbf{F}_{\text {hitung }}=2,801$ lebih besar dari $\mathbf{F}_{\text {tabel(18/10:0,05) }}=2,80$. Kesimpulan yang dapat diambil adalah regresi $\hat{\mathbf{Y}}=63,15+0,709 \mathrm{X}_{1}$ sangat signifikan. Hasil perhitungan diperoleh Koefisien korelasi $r=0,742$, sehingga besar koefisien determinasi $r^{2}=0,55$. Koefisien korelasi ini ternyata sangat signifikan setelah diuji melalui $\mathrm{F}$ ataupun uji $\mathrm{t}\left(\mathrm{t}_{\text {hitung }}=5.856>\mathrm{t}_{\text {tabel }(\mathrm{n}=30: 0,05)}=1,70\right)$, sehingga dapat disimpulkan terdapat hubungan positif antara Sikap Kerja dengan Kinerja. 
Tabel 4. Menghitung Persamaan Regresi

Coefficients"

\begin{tabular}{ccccccc}
\hline & & \multicolumn{2}{c}{$\begin{array}{c}\text { Unstandardized } \\
\text { Coefficients }\end{array}$} & $\begin{array}{c}\text { Standardized } \\
\text { Coefficients }\end{array}$ & & \\
\cline { 2 - 5 } 1 & Model & B & Std. Error & Beta & T & Sig. \\
& (Constant) & 63.152 & 14.551 & & 4.340 & .000 \\
& SIKAPKERJA & .709 & .121 & .742 & 5.856 & .000 \\
\hline
\end{tabular}

a. Dependent Variable: KINERJA

Sumber: data diolah

Tabel 5. Perhitungan Koefisien Korelasi

\begin{tabular}{|c|c|c|c|c|c|c|c|c|c|c|}
\hline \multicolumn{11}{|c|}{ Model Summary $^{\mathrm{b}}$} \\
\hline \multirow[b]{2}{*}{ Model } & \multirow[b]{2}{*}{$\mathrm{R}$} & \multirow[b]{2}{*}{$\begin{array}{c}\mathrm{R} \\
\text { Square }\end{array}$} & \multirow[b]{2}{*}{$\begin{array}{l}\text { Adjuste } \\
\mathrm{d} R \\
\text { Square }\end{array}$} & \multirow[b]{2}{*}{$\begin{array}{l}\text { Std. Error } \\
\text { of the } \\
\text { Estimate }\end{array}$} & \multicolumn{5}{|c|}{ Change Statistics } & \multirow[b]{2}{*}{$\begin{array}{l}\text { Durbin- } \\
\text { Watson }\end{array}$} \\
\hline & & & & & $\begin{array}{l}\text { R Square } \\
\text { Change }\end{array}$ & F Change & $\mathrm{df1}$ & $\mathrm{df} 2$ & $\begin{array}{c}\text { Sig. F } \\
\text { Change }\end{array}$ & \\
\hline 1 & $.742^{\mathrm{a}}$ & .550 & .534 & 5.340 & .550 & 34.289 & 1 & 28 & .000 & 1.817 \\
\hline
\end{tabular}

a. Predictors: (Constant), SIKAPKERJA

b. Dependent Variable: KINERJA

Sumber: data diolah

Dengan koefisien determinasi $r^{2}=0,55$, dapat disimpulkan bahwa $55 \%$ variasi yang terjadi dalam baiknya kinerja di sumbangkan oleh sikap kerja, selebihnya oleh variabel lain, serta dapat dipredik melalui sikap kerja, dengan persamaan regresi linear sederhana $\hat{\mathbf{Y}}=63,15+0,709 X_{1}$. Dengan pengujian ini menunjukkan bahwa keeratan hubungan dan pengaruh sikap kerja terhadap peningkatan kinerja di lingkungan PT Kinanty Patopang Jakarta yang cukup berarti. Hasil pengujian regresi sederhana $\mathrm{Y}$ atas $\mathrm{X}_{2}$ diperoleh persamaan regresi $\hat{Y}=66,21+0,683 X_{2}$. Secara keseluruhan pengujian signifikansi hubungan antara motivasi kerja terhadap kinerja karyawan, digambarkan dalam tabel dibawah ini.

Tabel 6. Analisis Varians Regresi $Y$ atas $X_{2}$ dengan model regresi

$$
\hat{Y}=66,21+0,683 X_{2}
$$

\begin{tabular}{ccccccc}
\hline \multicolumn{8}{c}{ ANOVA $^{\mathbf{b}}$} \\
\hline & Model & Sum of Squares & Df & Mean Square & F & Sig. \\
\hline 1 & Regression & 726.674 & 1 & 726.674 & 19.387 & $.000^{\circ}$ \\
& Residual & 1049.492 & 28 & 37.482 & & \\
& Total & 1776.167 & 29 & & & \\
\hline
\end{tabular}

a. Predictors: (Constant), MOTIVASI

b. Dependent Variable: KINERJA

Sumber: data diolah 
Tabel 7. Koefisien Regresi

Coefficients $^{\mathrm{a}}$

\begin{tabular}{|c|c|c|c|c|c|c|}
\hline & \multirow[b]{2}{*}{ Model } & \multicolumn{2}{|c|}{$\begin{array}{l}\text { Unstandardized } \\
\text { Coefficients }\end{array}$} & \multirow{2}{*}{$\begin{array}{c}\begin{array}{c}\text { Standardized } \\
\text { Coefficients }\end{array} \\
\text { Beta }\end{array}$} & \multirow[b]{2}{*}{$\mathrm{T}$} & \multirow[b]{2}{*}{ Sig. } \\
\hline & & $\mathrm{B}$ & Std. Error & & & \\
\hline \multirow[t]{2}{*}{1} & (Constant) & 66.217 & 18.645 & & 3.551 & .001 \\
\hline & MOTIVASI & .683 & .155 & .640 & 4.403 & .000 \\
\hline
\end{tabular}

a. Dependent Variable: KINERJA

Sumber: data diolah

Dari tabel di atas, terbukti bahwa uji regresi $\mathbf{F}_{\text {hitung }}=19,38$ lebih besar dari $\mathbf{F}_{\text {tabel(1/28:0,05) }}=$ 4,20 dan uji linieritas $\mathbf{F}_{\text {hitung }}=4,20$ lebih besar dari $\mathbf{F}_{\text {tabel(16/12:0,05) }}=2,60$. Kesimpulan yang dapat diambil adalah regresi $\hat{\mathbf{Y}}=\mathbf{6 6 , 2 1}+\mathbf{0 , 6 8 3} \mathrm{X}_{2}$ sangat signifikan.

Hasil perhitungan diperoleh Koefisien korelasi (r) sebesar 0,640, sehingga besar koefisien determinasi $\left(r^{2}\right)$ sebesar 0,409 . Koefisien korelasi ini ternyata sangat signifikan setelah diuji baik melalui $F$ ataupun uji $t\left(t_{\text {hitung }}=4.403>t_{\text {tabel }(n=30: 0,05)}=1,70\right)$, sehingga dapat disimpulkan bahwa terdapat hubungan positif antara motivasi dengan kinerja karyawan.

Tabel 8. Perhitungan Koefisien Korelasi

Model Summary

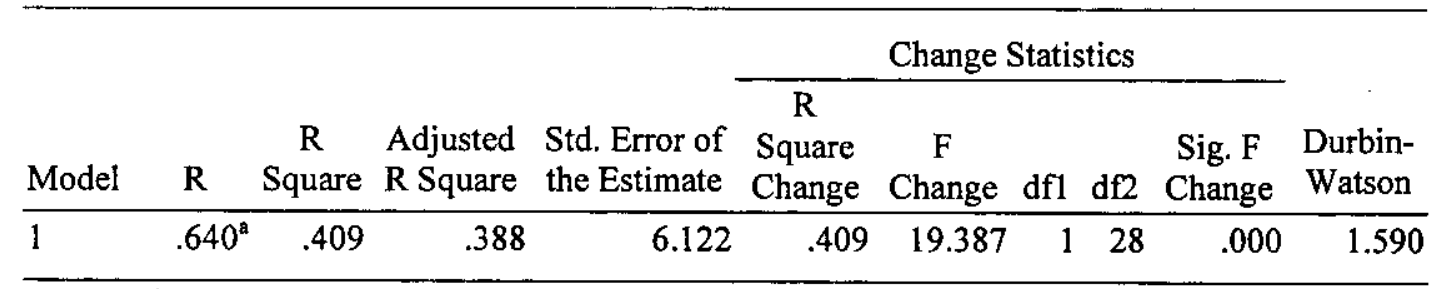

a. Predictors: (Constant), MOTIVASI

b. Dependent Variable: KINERJA

Sumber: data diolah

Dengan koefisien determinasi $\left(r^{2}\right)=0,409$, dapat disimpulkan bahwa $40,9 \%$ variasi yang terjadi dalam meningkatnya kinerja disumbangkan oleh variabel motivasi, selebihnya oleh variabel lain, serta dapat diprediksi melalui variabel motivasi, dengan persamaan regresi linear sederhana $\hat{\mathbf{Y}}=\mathbf{6 6 , 2 7}+\mathbf{0 , 6 8 3} \mathbf{X}_{2}$. Hasil pengujian ini menunjukkan bahwa keeratan hubungan dan pengaruh motivasi terhadap kinerja karyawan dapat dibuktikan berdasarkan hasil penelitian.

Analisis regresi linear jamak kinerja $(Y)$ terhadap sikap kerja $\left(X_{1}\right)$ dan motivasi $\left(X_{2}\right)$, menghasilkan persamaan regresi $\hat{Y}=43,28+0,53 X_{1}+0,34 X_{2}$. Hasil pengujian signifikansi hubungan antara sikap kerja dan motivasi terhadap kinerja, digambarkan dalam tabel dibawah ini. 
Tabel 9. Analisis Varians Regresi $Y$ atas $X_{1}$ dan $X_{2}$ dengan model regresi

$$
\hat{\mathrm{Y}}=43,28+0,53 \mathrm{X}_{1}+0,34 \mathrm{X}_{2}
$$

ANOVA $^{b}$

\begin{tabular}{ccccccc}
\hline & Model & Sum of Squares & Df & Mean Square & F & Sig. \\
\hline 1 & Regression & 1098.737 & 2 & 549.368 & 21.896 & $.000^{\mathrm{a}}$ \\
Residual & 677.430 & 27 & 25.090 & & \\
& Total & 1776.167 & 29 & & & \\
\hline
\end{tabular}

a. Predictors: (Constant), SIKAPKERJA, MOTIVASI

b. Dependent Variable: KINERJA

Sumber: data diolah

Tabel 10 . Perhitungan Regresi

Coefficients $^{\mathrm{a}}$

\begin{tabular}{|c|c|c|c|c|c|c|}
\hline & \multirow[b]{2}{*}{ Model } & \multicolumn{2}{|c|}{$\begin{array}{c}\text { Unstandardized } \\
\text { Coefficients }\end{array}$} & \multirow{2}{*}{$\begin{array}{c}\text { Standardized } \\
\text { Coefficients }\end{array}$} & \multirow[b]{2}{*}{$\mathrm{T}$} & \multirow[b]{2}{*}{ Sig. } \\
\hline & & B & Std. Error & & & \\
\hline \multirow[t]{2}{*}{1} & $\begin{array}{c}\text { (Constant) } \\
\text { SIKAPKERJA }\end{array}$ & $\begin{array}{l}43.280 \\
.534\end{array}$ & $\begin{array}{c}16.377 \\
.139\end{array}$ & .559 & $\begin{array}{l}2.643 \\
3.851\end{array}$ & $\begin{array}{l}.014 \\
.001\end{array}$ \\
\hline & MOTIVASI & .340 & .155 & .319 & 2.196 & .037 \\
\hline
\end{tabular}

a. Dependent Variable: KINERJA

Sumber: data diolah

Dari tabel di atas, terbukti bahwa uji regresi $\mathbf{F}_{\text {hitung }}=21,896$ lebih besar dari $\mathbf{F}_{\text {tabel(2/27:0,05) }}$ $=3,35$. Kesimpulan yang dapat diambil adalah model regresi $\hat{\mathbf{Y}}=\mathbf{4 3 , 2 8}+\mathbf{0 , 5 3} \mathbf{X}_{\mathbf{1}}+$ $\mathbf{0 , 3 4} \mathbf{X}_{2}$ sangat signifikan.

Hasil perhitungan diperoleh Koefisien korelasi (r) sebesar 0,787, sehingga besar koefisien determinasi $\left(r^{2}\right)$ sebesar 0,619 . Koefisien korelasi ini ternyata sangat signifikan setelah diuji melalui uji $\mathrm{F}\left(\mathrm{F}_{\text {hitung }}=21.896>\mathrm{F}_{\text {tabel(2/27:0,05) }}=3,35\right)$, sehingga dapat disimpulkan bahwa terdapat hubungan positif antara sikap kerja dan motivasi kerja secara bersama-sama dengan kinerja karyawan.

Tabel 11. Perhitungan Koefisien Korelasi

Model Summary

\begin{tabular}{|c|c|c|c|c|c|c|c|c|c|c|c|}
\hline \multirow[b]{3}{*}{ Model } & \multirow[b]{3}{*}{$\mathrm{R}$} & \multirow{3}{*}{$\begin{array}{c}\mathrm{R} \\
\text { Square }\end{array}$} & \multirow{3}{*}{$\begin{array}{l}\text { Adjusted } \\
\text { R Square }\end{array}$} & \multirow{3}{*}{$\begin{array}{l}\text { Std. Error } \\
\text { of the } \\
\text { Estimate }\end{array}$} & \multicolumn{6}{|c|}{ Change Statistics } & \multirow{3}{*}{$\begin{array}{l}\text { Durbin- } \\
\text { Watson }\end{array}$} \\
\hline & & & & & $\mathrm{R}$ Squar & & & & Sig. & $\mathrm{F}$ & \\
\hline & & & & & Change & Change & $\mathrm{df1}$ & $\mathrm{df} 2$ & Change & & \\
\hline 1 & $.787^{\mathrm{a}}$ & .619 & .590 & 5.009 & .619 & 21.896 & 2 & 27 & .000 & & 1.620 \\
\hline
\end{tabular}

a. Predictors: (Constant), SIKAPKERJA

b. Dependent Variable: MOTIVASI

Sumber: data diolah

Hasil pengujian tersebut memperlihatkan adanya hubungan positif antara sikap kerja dan motivasi dengan kinerja. Artinya semakin baik sikap kerja dan semakin tinggi motivasi terhadap pekerjaan akan semakin meningkatkan kinerja. Dari koefisien determinasi $\left(\mathrm{r}^{2}\right)=$ 


\title{
PENGARUH PRAKTEK TOTAL QUALITY MANAGEMENT (TQM) TERHADAP KINERJA OPERASIONAL DAN BUDAYA ORGANISASI SEBAGAI VARIABEL ANTESEDEN
}

\author{
Ngadiman \& Munawar Muchlish \\ Fakultas Ekonomi Universitas Tarumanagara \& Fakultas Ekonomi Untirta Banten \\ Emal:ngadiman_ngadiman@yahoo.com
}

\begin{abstract}
The purpose of this study was to analyze the Practice Effect of Total Quality Management (TQM) to the Operational Performance and Organizational Culture as Antecedents Variables. The data used in this study were obtained from the perception of the general manager, operations and production is functionally involved in managerial performance in manufacturing companies in Banten. Of the 150 questionnaires distributed, the number of questionnaires returned was 48 questionnaire. Analysis of the data using the approach of Partial Least Square (PLS) using software SmartPLS. This research was conducted in a Manufacturing Company Banten, with the object of study is the manager of marketing, production and finance. This study uses survey research with primary data collection using questionnaires. The selection of samples tested in this study using purposive sampling method, 48 respondents selected as the study sample. Testing research hypotheses with the inner models. The results of this study (1) there is a significant positive effect between the dimensions of organizational culture with the instrument team work / respect for others with the level of use of TQM practices, (2) The dimensions of the organizational culture of innovation instruments do not have a positive effect with the level of use of the practice of TQM (Total Quality Management Supplier), (3) Dimensions of organizational culture with the instrument innovation has a positive effect with the level of use of TQM practices (process management), (4) management processes to positively influence the performance of inventory management and quality performance. (5) management process with no positive effect of inventory management, thus rejecting the hypothesis.
\end{abstract}

Keywords: TQM, Operational Performance, Organizational Culture, PLS

Abstrak: Tujuan dari penelitian ini adalah untuk menganalisis Pengaruh Praktek Total Quality Management (TQM) terhadap Kinerja Operasional dan Budaya Organisasi sebagai Variabel Anteseden. Data yang digunakan di penelitian ini diperoleh dari persepsi manajer umum, operasional dan produksi yang terlibat secara fungsional pada kinerja manajerial pada perusahaan manufaktur di Banten. Dari 150 kuesioner yang disebarkan, jumlah kuesioner yang kembali adalah 48 kuesioner. Analisis data menggunakan pendekatan Partial Least Square (PLS) dengan menggunakan software SmartPLS. Penelitian ini dilaksanakan di Perusahaan Manufaktur se-Banten, dengan objek penelitian adalah manajer pemasaran, produksi dan keuangan. Penelitian ini menggunakan metode penelitian survei dengan pengumpulan data primer yang menggunakan kuesioner. Pemilihan sampel yang diuji dalam penelitian ini menggunakan metode purposive sampling, terpilih 48 responden sebagai sampel penelitian. Pengujian hipotesis penelitian dengan inner model. Hasil dari penelitian ini (1) terdapat pengaruh positif signifikan antara dimensi budaya organisasi dengan 
instrumen kerja tim / menghormati orang lain dengan tingkat penggunaan praktek TQM, (2) Dimensi budaya organisasi dengan instrumen inovasi tidak memiliki berpengaruh positif dengan tingkat penggunaan praktek TQM (Manajemen Kualitas Suplier), (3) Dimensi budaya organisasi dengan instrumen inovasi berpengaruh positif dengan tingkat penggunaan praktek TQM (Manajemen Proses), (4) manajemen proses berpengaruh positif dengan kinerja manajemen persediaan dan kinerja kualitas. (5) manajemen proses tidak berpengaruh positif dengan manajemen persediaan, sehingga menolak hipotesis.

Kata Kunci: TQM, Kinerja Operasional, Budaya Organisasi, PLS

\section{PENDAHULUAN}

Pada era persaingan global dewasa ini, tuntutan konsumen atas peningkatan kualitas produk atau jasa terus bertambah (Wicaksono, 2006). Suatu produk yang berkualitas tidak hanya merupakan produk dengan performance yang baik tetapi juga harus memenuhi kriteria kepuasan konsumen (Ciptani, 1999). Hal ini merupakan faktor yang sangat penting bagi perusahaan terutama dalam persaingan bisnis yang begitu ketat.

Dunia sebagai suatu pasar global telah memungkinkan aktivitas ekonomi bergerak tanpa mengenal adanya batasan lintas antar negara. Diperlukan kemampuan lintas budaya yang efektif untuk berhasil dalam kompetisi perusahaan di tingkat global. Untuk memperoleh keunggulan daya saing dalam skala global, perusahaan harus menerapkan budaya kualitas di dalam setiap aktivitas kerja dan sebagai faktor yang penting serta kunci utama dalam mempertahankan keunggulan kompetitif. Perusahaan yang berorientasi pada kualitas, fokus utamanya adalah kepuasan pelanggan. Untuk memenuhi kualitas produk atau jasa yang dapat memuaskan pelanggan, salah satu cara yang tepat adalah dengan mengimplementasikan praktek Total Quality Management (TQM) yang dianggap dapat membantu perusahaan untuk memenuhi keinginan pelanggan (Malahayati, 2010).

Total Quality Management (TQM) adalah suatu filosofi integratif manajemen yang ditujukan untuk terus meningkatkan kualitas produk / jasa dan proses dalam rangka untuk memenuhi atau melebihi harapan pelanggan (Prajogo dan McDermott, 2005; Kiella dan Golhar, 1997; Departemen Perdagangan AS, 1994), Dan untuk memenuhi harapan pelanggan tersebut, budaya dalam suatu organisasi harus dikembangkan dengan baik. Meskipun banyak penelitian yang telah menunjukkan bahwa banyak perusahaan telah berhasil dengan menggunakan strategi kualitas, American Quality Foundation dan Ernst \& Young (1992) menemukan bahwa hampir dua pertiga dari perusahaan di AS melihat nilai "keuntungan kompetitif nol" dari pelaksanaan TQM, sementara itu mayoritas organisasi di Inggris belum menerima hasil apapun yang nyata dari TQM (Soltani et al. 2005).

Hasil temuan yang beragam mengenai keberhasilan praktek TQM menimbulkan pertanyaan, apakah perusahaan terlibat atau tidak dengan praktek TQM, dan faktor apa yang dapat berkontribusi terhadap keberhasilan TQM. Keterkaitan antara implementasi TQM dengan budaya dikemukakan oleh Cortada (dalam Wicaksono, 2006), bahwa implementasi TQM dapat merubah orientasi budaya suatu organisasi menuju budaya kualitas yang pada akhirnya dapat meningkatkan kompetensi organisasi.

Menurut Wicaksono (2006) dalam implementasi TQM, budaya lebih berperan daripada yang lainnya, oleh karena itu budaya kualitas dipertimbangkan sebagai salah satu hal yang terpenting sebagai indikator keberhasilan implementasi TQM. Oleh karena itu 
alasan pemilihan variabel budaya organisasi dalam penelitian ini adalah budaya organisasi merupakan salah satu faktor penentu keberhasilan praktek TQM. Sebuah budaya organisasi yang kondusif merupakan hal yang penting untuk pelaksanaan praktik TQM. Banyak peneliti yang berpendapat bahwa keberhasilan pelaksanaan TQM adalah bergantung pada budaya organisasi yang berlaku, dan perlunya mengubah budaya organisasi dan sikap tenaga kerja agar pelaksanaan TQM menjadi efektif.

Meskipun peran penting dari budaya organisasi sudah mendapat pengakuan luas dalam memastikan keberhasilan pelaksanaan TQM, namun ada perbedaan dalam literatur empiris yang meneliti pengaruh antara budaya organisasi dan penerapan praktik TQM yaitu; kualitas data dan pelaporan, manajemen kualitas pemasok, dan manajemen proses. (Kaynak, 2003) Tujuan dari penelitian ini adalah untuk menginvestigasi dimensi budaya menurut O'Reilly et al's. yaitu kerja tim/menghormati orang lain, dan inovasi terhadap penggunaan praktek TQM dan penelitian ini menyoroti pentingnya budaya organisasi, dengan berfokus pada dampak berikutnya dari penggunaan praktek TQM di perusahaan manufaktur.

Budaya Organisasi. Menurut Hofstede (1990), budaya bukanlah perilaku yang jelas atau benda yang dapat terlihat dan diamati seseorang. Budaya juga bukan falsafah atau sistem nilai yang diucapkan atau ditulis dalam anggaran dasar organisasi tetapi budaya adalah asumsi yang terletak di belakang nilai dan menentukan pola perilaku individu terhadap nilai-nilai organisasi, suasana organisasi dan kepemimpinan. Organisasi dengan budaya tertentu- memberikan daya tarik bagi individu dengan karakteristik tertentu untuk bergabung. Budaya organisasi bersifat nonformal atau tidak tertulis namun mempunyai peranan penting sebagai cara berpikir, menerima keadaan dan merasakan sesuatu dalam perusahaan tersebut.

Kerja tim/menghormati orang lain. Kerja tim/menghormati orang lain mengacu pada kolaborasi antara karyawan dan atau unit kerja dalam sebuah perusahaan dan sejauh mana mereka fokus pada keadilan untuk menghormati setiap hak-hak individu, dan toleransi terhadap sesama (Windsor dan Ashkanasy, 1996). Pengertian lain dari kerja tim adalah tingkat aktivitas pekerjaan yang diatur dalam tim, bukan secara perorangan.

Inovasi. Inovasi adalah tingkat daya pendorong karyawan untuk bersikap inovatif. Inovasi dapat diartikan sebagai proses dan/atau hasil pengembangan pemanfaatan dari pengetahuan keterampilan (termasuk keterampilan teknologis) dan pengalaman untuk menciptakan atau memperbaiki produk (barang dan/atau jasa), proses, dan/atau sistem yang baru, yang memberikan nilai yang berarti atau secara signifikan (terutama ekonomi dan sosial). Inovasi sebagai suatu "objek" juga memiliki arti sebagai suatu produk atau praktik baru yang tersedia bagi aplikasi, umumnya dalam suatu konteks komersial. Biasanya, beragam tingkat kebaruannya dapat dibedakan, bergantung pada konteksnya: suatu inovasi dapat bersifat baru bagi suatu perusahaan (O'Reilly et al., 1991).

TQM (Total Quality Management). TQM atau total manajemen kualitas adalah strategi manajemen yang ditujukan untuk menanamkan kesadaran pentingnya kualitas pada semua proses dalam organisasi. Sesuai dengan definisi dari ISO, TQM adalah suatu pendekatan manajemen untuk suatu organisasi yang terpusat pada kualitas, berdasarkan partisipasi semua anggotanya dan bertujuan untuk kesuksesan jangka panjang melalui kepuasan pelanggan serta memberi keuntungan untuk semua anggota dalam organisasi serta masyarakat. 
Kaynak (2003) menjelaskan bahwa TQM adalah sebuah filosofi manajemen yang holistik yang berusaha untuk melakukan perbaikan terus-menerus di semua fungsi, lini maupun divisi organisasi, dan dapat dicapai hanya jika konsep kualitas terpadu dimanfaatkan dengan memanfaatkan sumber daya yang ada untuk pelayanan konsumen purna jual. Definisi ini menjelaskan kepada kita semua bahwa TQM merupakan konsep yang menyatu dan menyeluruh dalam sebuah organisasi.

Kualitas Data dan Pelaporan. Dalam praktek TQM, kualitas data dan pelaporan mengacu pada sejauh mana kualitas data dikumpulkan, dipantau, dan digunakan untuk tujuan peningkatan kualitas (Gotzamani dan Tsiotras, 2001). Kualitas data dan pelaporan yang tepat waktu, akurat dan dapat diandalkan digunakan untuk mengelola kualitas. Kualitas data dan pelaporan secara langsung mempengaruhi manajemen proses dengan menginformasikan para pekerja tentang kekurangan dalam proses sehingga mereka dapat segera mengambil tindakan korektif sebelum produk yang cacat dihasilkan (Ahire dan Dreyfus, 2000; Handfield et al, 1998; Flynn et al, 1995).

Manajemen Kualitas Supplier. Manajemen kualitas supplier meliputi hal membangun kemitraan, rasa saling percaya, dan pertumbuhan yang sejajar dengan pemasok (Gotzamani dan Tsiotras, 2001). Manajemen kualitas supplier yang efektif difasilitasi dengan hubungan kerjasama jangka panjang, dengan supplier untuk mendapatkan bahanbahan dan / atau jasa yang berkualitas (Kaynak, 2003).

Manajemen Proses. Manajemen proses meliputi dokumentasi secara sistematis dan kontrol dari proses kritis dan kualitas produk (Gotzamani dan Tsiotras, 2001). Manajemen proses yaitu suatu pendekatan preventif untuk meningkatkan kualitas, memusatkan perhatian pada desain proses yang mendekati sempurna dan menstabilkan jadwal produksi dan distribusi kerja (Flynn et al, 1995; Saraph et al, 1989). Manajemen proses merupakan usaha untuk mengurangi variasi dalam proses produksi (Ho et al, 1999; Flynn et al, 1995). Dengan melakukan manajemen proses dapat mengurangi variasi hasil proses dalam keseragaman output yang lebih baik serta dapat mengurangi pengerjaan ulang dan sisa limbah (Forza dan Filippini, 1998).

Kinerja Operasional. Mahoney et al. (1963) menyatakan kinerja (performance) adalah hasil kerja yang dapat dicapai oleh seseorang atau sekelompok orang dalam suatu organisasi, sesuai dengan wewenang dan tanggung jawab masing-masing, dalam rangka mencapai tujuan organisasi.

Kinerja Manajemen Persediaan. Perusahaan yang menerapkan TQM mengalami tingkat perputaran persediaan tinggi, hal ini merupakan suatu situasi yang memungkinkan untuk mengidentifikasi masalah penjadwalan dan produksi (Krajewski dan Ritzman, 2001). Produsen berada di bawah tekanan untuk mempertahankan tingkat persediaan yang rendah, hal ini disebabkan karena kenaikan biaya opportunity, biaya penyimpanan dan penanganan, pajak, asuransi dan biaya penyusutan. Tetapi pada saat yang bersamaan, mereka juga berada di bawah tekanan untuk mempertahankan tingkat persediaan yang cukup untuk memenuhi kebutuhan layanan pelanggan, meminimalkan biaya set up, dan menggunakan sepenuhnya tenaga kerja dan peralatan. Manajemen persediaan yang efektif sangat penting bagi perusahaan untuk menyeimbangkan tekanan kebutuhan persediaan yang rendah atau tinggi dan menyusun tingkat yang sesuai dengan persediaan (Balakrishnan et al., 1996). 
Kinerja Kualitas. Perusahaan yang menerapkan TQM didorong untuk melakukan perbaikan terus-menerus dari proses dan kualitas produk (Kaynak, 2003). Perbaikan ini harus dapat meningkatkan kualitas produk / layanan, mengurangi biaya cacat dan pengerjaan ulang, mengurangi lead time dan meningkatkan produktivitas.

Pengembangan Hipotesis. Pengaruh antara budaya organisasi dan TQM. Tujuan pertama dari penelitian ini adalah untuk meneliti pengaruh antara budaya organisasi dan TQM. Analisis pengaruh antara budaya organisasi dan TQM bermasalah dengan perdebatan mengenai apakah ada perbedaan antara budaya organisasi dan TQM ini. Meskipun budaya organisasi dan TQM terkait erat kedua hal tersebut sebenarnya berbeda. Schein (1985) dan Powell (1995) keduanya mendukung pembedaan antara budaya dan TQM, yang menyatakan bahwa praktek-praktek seperti TQM mungkin mencerminkan budaya dalam suatu organisasi, namun budaya organisasi itu sendiri lebih tertanam dalam organisasi yang mencerminkan pola dan keyakinan yang stabil dan nilai-nilai yang dikembangkan dalam suatu perusahaan (atau unit bisnis) dari waktu ke waktu.Studi ini meneliti dimensi-dimensi tertentu dari budaya yang secara terpisah mempengaruhi tingkat pelaksanaan praktek TQM. Enam dimensi dengan instrumen profil budaya organisasi (Organization Culture Profile), yang diambil dari O'Reilly et al. (1991), diantaranya: orientasi terhadap hasil, perhatian terhadap detail, kerja tim / menghormati orang lain, inovasi, stabilitas, dan agresivitas. Namun di dalam penelitian ini hipotesis hanya dikembangkan sehubungan dengan dua dimensi yaitu kerja tim / menghormati orang lain, dan inovasi.

Kerja sama tim/menghormati orang lain mengacu pada kolaborasi antara karyawan dan/atau unit kerja dalam sebuah perusahaan dan sejauh mana mereka fokus pada keadilan untuk menghormati setiap hak-hak individu, dan toleransi terhadap sesama (Windsor dan Ashkanasy, 1996). Kerja sama tim meningkatkan fleksibilitas dan mempersingkat jeda waktu dalam menanggapi variasi dan ketidakpastian dalam proses produksi atau jasa (Flynn dan Schroeder, 1994), sehingga berkontribusi untuk perbaikan terus menerus dalam proses produksi. Oleh karena itu, organisasi yang mendorong kerja tim / menghormati orang lain diharapkan menggunakan praktek TQM untuk tingkat yang lebih besar, karena kerja sama tim merupakan bagian terpenting dari kesuksesan adopsi dan pelaksanaan TQM. Berdasarkan uraian di atas maka hipotesis sebagai berikut:

H1a. Dimensi budaya organisasi dengan instrumen kerja tim / menghormati orang lain akan berpengaruh positif dengan tingkat penggunaan praktek TQM (Kualiatas Data Pelaporan).

H1b. Dimensi budaya organisasi dengan instrumen kerja tim / menghormati orang lain akan berpengaruh positif dengan tingkat penggunaan praktek TQM (Manajemen Kualitas Suplier).

H1c. Dimensi budaya organisasi dengan instrumen kerja tim / menghormati orang lain akan berpengaruh positif dengan tingkat penggunaan praktek TQM (Manajemen Proses).

TQM membutuhkan perusahaan yang terus menerus mencari cara untuk meningkatkan proses kerja sehingga meningkatkan kemampuan mereka untuk menghasilkan produk/jasa yang berkualitas tinggi. Perusahaan yang memiliki inovasi akan lebih bersedia untuk bereksperimen dengan praktek-praktek baru seperti praktek TQM. Mereka akan terus mengevaluasi kebutuhan pelanggan dan ekspektasi pasar dalam rangka untuk mengembangkan produk dan layanan baru dan meningkatkan proses produksi saat ini (Juran, 1988). Oleh karena itu, perusahaan yang lebih berinovasi lebih mungkin untuk 
mengadopsi dan membuat ekstensif penggunaan praktek TQM. Secara formal hipotesis selanjutnya dinyatakan sebagai berikut:

H2a. Dimensi budaya organisasi dengan instrumen inovasi akan berpengaruh positif dengan tingkat penggunaan praktek TQM (Manajemen Kualitas Suplier) .

H2b. Dimensi budaya organisasi dengan instrumen inovasi akan berpengaruh positif dengan tingkat penggunaan praktek TQM (Manajemen Proses).

Pengaruh antara praktek TQM dan kinerja operasional. Bagian berikut mengembangkan hipotesis yang relevan dalam hal hubungan antara masing-masing praktek inti TQM dengan satu sama lain dan dengan dua variabel kinerja operasional (Kaynak, 2003).

Manajemen Kualitas Supplier. Manajemen kualitas supplier melibatkan pengembangan kemitraan dekat, rasa saling percaya, dan pertumbuhan yang sejajar dengan supplier. Manajemen kualitas supplier yang efektif difasilitasi dengan hubungan kerjasama jangka panjang, dengan supplier untuk mendapatkan bahan-bahan dan/atau jasa yang berkualitas.

Manajemen supplier juga membantu produsen untuk pengadaan bahan dan bagian yang dapat digunakan secara efisien. Supplier yang memiliki sertifikasi atau program kualifikasi memberikan jaminan tentang kualitas bahan yang masuk dan bagian dengan cara menyampaikan harapan kualitas produsen untuk supplier. Oleh karena itu, diharapkan bahwa manajemen supplier akan mengakibatkan manajemen persediaan yang lebih baik (Kaynak, 2003). Maka hipotesis sebagai berikut:

H3a. Manajemen kualitas supplier secara positif terkait dengan kinerja manajemen persediaan. Akhirnya, keseluruhan kualitas produk dipengaruhi oleh manajemen kualitas supplier yang efektif. Secara khusus, dengan kehandalan rantai persediaan material dari supplier yang kompeten dan fleksibel dapat meningkatkan kualitas produk akhir. Maka hipotesis sebagai berikut:

H3b. Manajemen kualitas supplier secara positif berpengaruh dengan kinerja kualitas.

Manajemen Proses. Forza dan Filippini (1998) menemukan bahwa manajemen proses secara langsung dan positif mempengaruhi kualitas produk. Demikian pula, Flynn et al. (1995) menemukan bahwa manajemen proses yang efektif menghasilkan peningkatan dalam persentase kelolosan barang-barang melewati inspeksi akhir tanpa adanya permintaan pengerjaan ulang. Berdasarkan pembahasan di atas, dan sejalan dengan penelitian Kaynak (2003), hipotesis manajemen proses secara positif berpengaruh dengan kinerja kualitas. Maka hipotesis sebagai berikut :

H4a. Manajemen proses secara positif berpengaruh dengan kinerja kualitas.

Dengan berfokus pada penyempurnaan proses produksi untuk menghilangkan ketidakpastian dan mengurangi pemborosan dan pengerjaan ulang, manajemen proses juga dapat membantu dengan manajemen persediaan. Secara khusus, pemahaman yang lebih jelas tentang persyaratan dan spesifikasi produk membantu perusahaan ketika berhadapan dengan supplier dengan menjelaskan kuantitas bahan yang dibutuhkan dan memastikan pengiriman tepat waktu. Oleh karena itu, manajemen proses dapat memungkinkan perusahaan untuk mengembangkan manajemen persediaan mereka dengan meningkatkan kualitas pengiriman barang-barang tepat waktu dan memungkinkan penghapusan atau pengurangan cadangan persediaan. Maka hipotesis sebagai berikut

H4b. Manajemen proses secara positif terkait dengan kinerja manajemen persediaan 
Model Penelitian. Kerangka pemikiran teoritis digambarkan dalam gambar berikut di bawah ini :

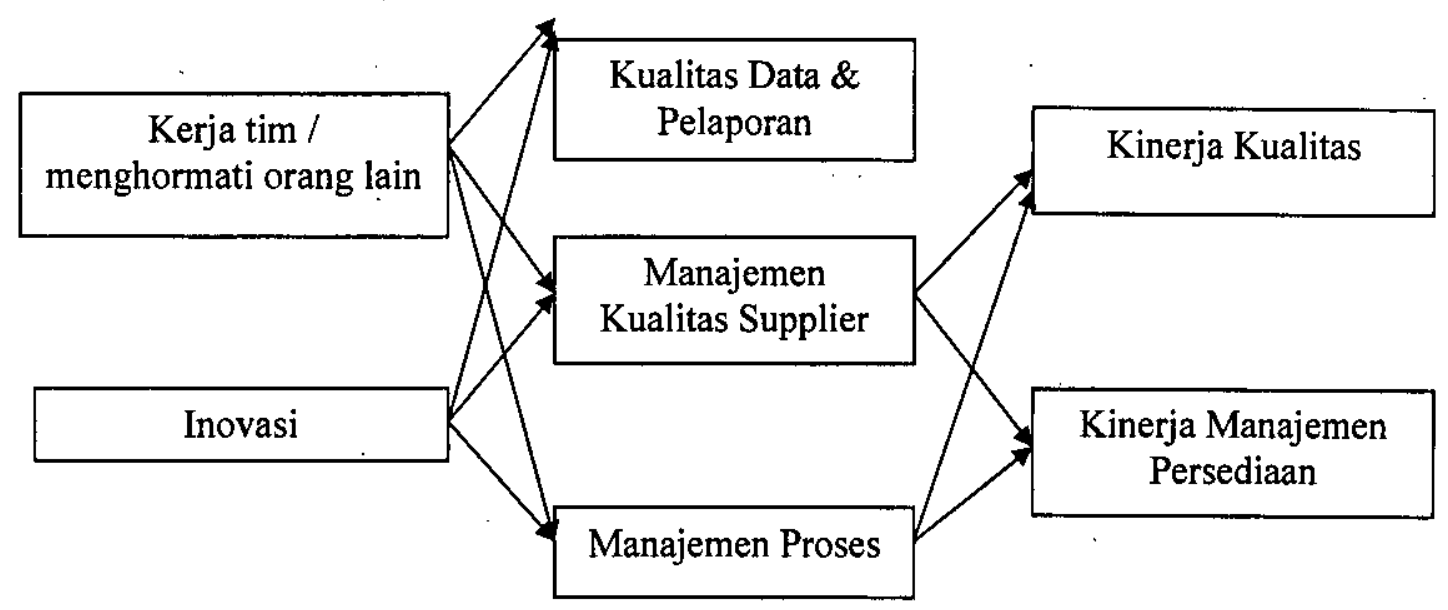

Gambar 1. Model Penelitian

Sumber: model yang dikembangkan dalam penelitian ini (2013)

\section{METODE}

Populasi dan Sampel. Populasi penelitian ini adalah perusahaan manufaktur yang ada di Banten yang telah mengadopsi praktek-praktek TQM. Dan telah disertifikasi oleh standar ISO. Berdasarkan kriteria yang telah ditentukan tersebut sampel penelitian ini terdiri dari Manajer Umum, Manajer Operasional, dan juga Manajer Produksi di perusahaan manufaktur yang ada di Banten. Manajer dipilih karena mereka dianggap akrab dengan penerapan TQM dan kinerja kualitas unit bisnis mereka. Pengumpulan data dilakukan dengan datang langsung ke wilayah yang dapat dijangkau. Teknik penentuan sampel dalam penelitian ini dengan menggunakan teknik Convenience Sampling. Kuesioner diantar langsung dan penyebaran kuesioner mengacu pada jumlah indikator dalam penelitian..

Variabel Penelitian. Untuk melakukan pengujian hipotesis yang diajukan, variabel yang diteliti perlu diukur. Dalam penelitian ini, variabel-variabel penelitian terdiri dari variabel eksogen dan variabel endogen. Variabel eksogen adalah "source variabel" atau "independent variabel" yang tidak diprediksi oleh variabel lain dalam model, sedangkan variabel endogen adalah variabel yang diprediksi oleh variabel lain.

Variabel Budaya Organisasi. Budaya organisasi dalam penelitian ini diperlakukan sebagai variabel anteseden dan memiliki dua dimensi konstruk dari instrumen profil budaya organisasi (Organization Culture Profile), yang diambil dari penelitian O'Reilly et al. (1991), yaitu kerja tim / menghormati orang lain, dan inovasi. Budaya organisasi menggunakan 12 item pertanyaan dari berbagai sumber (O'Reilly et al., 1991; Baird et al., 2011) dari item tersebut dibagi berdasarkan kepentingannya yaitu kerja tim / menghormati orang lain, dan inovasi.

Variabel Praktek TQM. Variabel praktek TQM yang diteliti dalam penelitian ini ada tiga yaitu kualitas data dan pelaporan, manajemen kualitas supplier, dan manajemen proses (Baird et al., 2011). Kualitas data dan pelaporan pengukurannya menggunakan 4 
item pertanyaan dari berbagai sumber (Kaynak, 2003). Manajemen kualitas supplier pengukurannya menggunakan 5 item pertanyaan dari berbagai sumber (Kaynak, 2003; Baird et al., 2011). Dan manajemen proses pengukurannya menggunakan 4 item pertanyaan dari berbagai sumber (Kaynak, 2003; Baird et al., 2011).

Variabel Kinerja Operasional. Kinerja operasional dalam penelitian ini ada dua yaitu kinerja manajemen persediaan dan kinerja kualitas. Kinerja manajemen persediaan pengukurannya menggunakan 3 item pertanyaan dari berbagai sumber (Kaynak, 2003; Schonberger, 1982). Dan kinerja kualitas pengukurannya menggunakan 6 item pertanyaan dari berbagai sumber (Kaynak, 2003; Ahire \& Dreyfus, 2000).

Metode Analisis Data. Teknik analisis data Dalam penelitian ini menggunakan pendekatan Partial Least Square (PLS) dengan menggunakan software SmartPLS. PLS adalah model persamaan struktural (SEM) yang berbasis komponen atau (variance). Menurut Ghozali (2006) PLS merupakan pendekatan alternative yang bergeser dari pendekatan SEM yang berbasis covariance menjadi berbasis varian. SEM yang berbasis kovarian umumnya menguji kualitas/teori sedangkan PLS lebih bersifat predictive model. PLS merupakan metode analisis yang powerfull (Wold dalam Ghozali ,2006) karena tidak banyak didasarkan pada banyak asumsi. Misalnya data harus terdistribusi normal, sampel tidak harus besar. Selain dapat digunakan untuk mengkonfirmasi teori, PLS juga dapat digunakan untuk menjelaskan ada tidaknya hubungan antara variabel laten. PLS dapat sekaligus menganalisis konstruk yang dibentuk dengan indikator refleksif dan formatif.

\section{HASIL DAN PEMBAHASAN}

Deskripsi Umum Responden. Demografi Responden. Seperti yang telah disebutkan sebelumnya, teknik penarikan sampel pada penelitian ini adalah menggunakan convenience sampling. Dengan asumsi response rate responden sebesar $20 \%$ yang diharapkan maka kuesioner yang disebarkan sebanyak 150 eksemplar. Untuk meningkatkan response rate, penelitian ini menggunakan metode penyampaian langsung dalam menyebarkan kuesioner sehingga response rate yang diperoleh sebesar $27.3 \%$ dari kuesioner yang dịkirim dan telah sesuai dengan kriteria. Berikut ditunjukkan pada tabel 1.

Tábel 1. Rincian Pengembalian Kuesioner

\begin{tabular}{|l|c|}
\hline \multicolumn{1}{|c|}{ Keterangan } & Jumlah \\
\hline Penyampaian langsung & 150 \\
\hline Kuesioner yang kembali & 48 \\
\hline Total Kuesioner yang digunakan & 48 \\
\hline Tingkat Pengembalian (Response Rate) $(41 / 150$ & \\
x $100 \%)$ & $32 \%$ \\
\hline Tingkat Pengembalian yang digunakan & $32 \%$ \\
\hline
\end{tabular}

Sumber: Data primer diolah (2013)

Pengujiann Kualitas Data. Uji Validitas. Pengujian validitas data dalam penelitian ini adalah dengan menggunakan software PLS dengan Outer Model yaitu Convergent validity yang dilihat dengan nilai square root of average variance extracted (AVE) masing-masing konstruk dimana nilainya harus lebih besar dari 0,5. Cara lain yaitu dengan membandingkan nilai square root of average variance extracted (AVE) setiap konstruk 
(variabel laten) dengan korelasi antara konstruk dengan konstruk lainnya dalam model. Jika nilai akar kuadrat AVE setiap konstruk lebih besar dari pada nilai korelasi antara konstruk dengan konstruk lainnya dalam model, maka dikatakan memiliki nilai discriminant validity yang baik.

Tabel 2. Average Variance Extracted (AVE)

\begin{tabular}{|l|c|c|} 
& Average variance extracted (AVE) & VAVE \\
\hline Kerja Tim & 0.515 & 0.847 \\
\hline Inovasi & 0.497 & 0.705 \\
\hline Kualitas data \& Pelaporan & 1.000 & 1.000 \\
\hline Manajemen Kualitas Suplier & 0.547 & 0.740 \\
\hline Manajemen Proses & 0.791 & 0.890 \\
\hline Kinerja Kualitas & 0.615 & 0.784 \\
\hline Kinerja Manajemen Persediaaan & 0.639 & 0.799 \\
\hline
\end{tabular}

Sumber: Output Smart PLS (2013)

Uji Reliabilitas. Begitu pula dengan uji reliabilitas, penelitian ini menggunakan software PLS dengan Composite Reliability. Suatu data dikatakan reliabel jika, composite reliability lebih dari 0,7 .

Tabel 3. Composite Reliability

\begin{tabular}{|l|c|}
\hline & Composite Reliability \\
\hline Kerja Tim & 0.804 \\
\hline Inovasi & 0.745 \\
\hline Kualitas data \& Pelaporan & 1.000 \\
\hline Manajemen Kualitas Suplier & 0.779 \\
\hline Manajemen Proses & 0.938 \\
\hline Kinerja Kualitas & 0.860 \\
\hline Kinerja Manajemen Persediaaan & 0.769 \\
\hline
\end{tabular}

Sumber: Output Smart PLS (2013)

Analisis Data. Menilai Outer Model (Measurement Model). Dalam menilai outer model dalam PLS, terdapat tiga kriteria, salah satunya adalah melihat Convergent Validity sedangkan untuk dua kriteria yang lain yaitu Discriminant Validity dalam bentuk square root of average variance extracted (AVE) dan Composite Reliability telah dibahas sebelumnya pada saat pengujian kualitas data. Untuk Convergent validity dari model pengukuran dengan refleksif indikator dinilai berdasarkan korelasi antara item score/component score yang diestimasi dengan software PLS. Ukuran refleksif individual dikatakan tinggi jika berkorelasi lebih dari 0,7 dengan konstruk (variabel laten) yang diukur. Namun menurut Chin dalam Ghozali $(2006$; 24), untuk penelitian tahap awal dari pengembangan, skala pengukuran nilai loading 0,5 sampai 0,6 dianggap cukup memadai. 


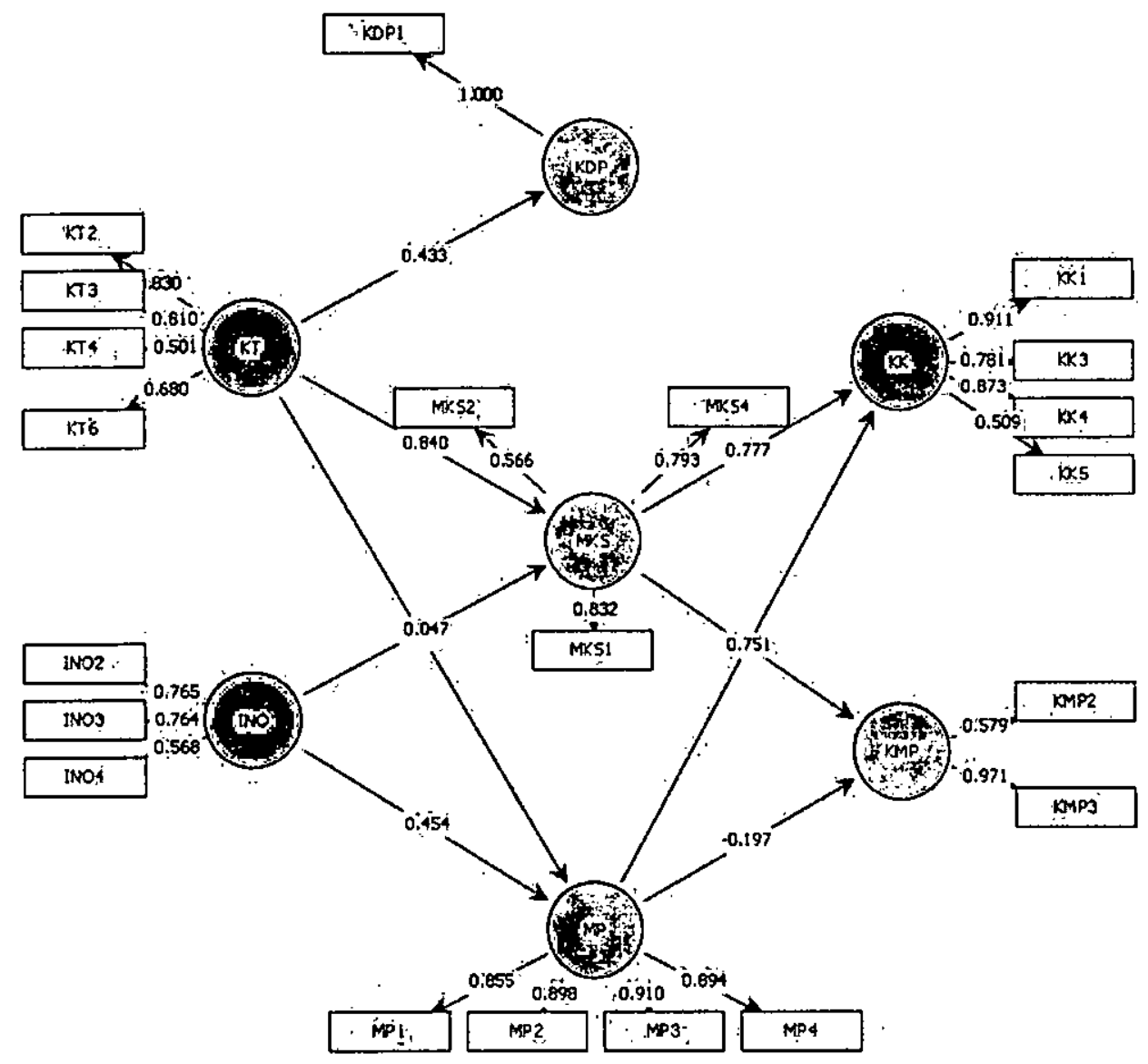

Gambar 2. Full Model StructuralPartial Least Square

Sumber: Output SmartPLS (2013)

Pengujian Hipotesis dengan Inner Model

Tabel 4. Results for inner weights

\begin{tabular}{|c|c|c|c|c|l|}
\hline & $\begin{array}{c}\text { original } \\
\text { sample } \\
\text { estimate }\end{array}$ & $\begin{array}{c}\text { mean of sub } \\
\text { samples }\end{array}$ & $\begin{array}{c}\text { Standard } \\
\text { deviation }\end{array}$ & T-Statistic & \multicolumn{1}{|c|}{ Keputusan } \\
\hline $\mathrm{KT}$ - KDP & 0.433 & 0.434 & 0.105 & 4.114 & Hla : didukung \\
\hline $\mathrm{KT}>\mathrm{MKS}$ & 0.840 & 0.842 & 0.068 & 12.274 & H1b : didukung \\
\hline $\mathrm{KT}>\mathrm{MP}$ & 0.426 & 0.402 & 0.112 & 3.793 & $\mathrm{H} 1 \mathrm{c}:$ didukung \\
\hline $\mathrm{NO}$ - MKS & 0.047 & 0.039 & 0.075 & 0.620 & H2a : tidak didukung \\
\hline
\end{tabular}




\begin{tabular}{|c|c|c|c|c|l|}
\hline INO > MP & 0.454 & 0.474 & 0.115 & 3.954 & H2b : didukung \\
\hline MKS -> KMP & 0.751 & 0.743 & 0.081 & 9.307 & H3a : didukung \\
\hline MKS -> KK & 0.777 & 0.754 & 0.070 & 11.033 & H3b : didukung \\
\hline MP - KK & 0.199 & 0.223 & 0.062 & 3.199 & H4a : didukung \\
\hline MP -> KMP & $-0.197-$ & -0.212 & 0.179 & 1.100 & H4b : Tidak didukung \\
\hline
\end{tabular}

Sumber: Output Smart PLS (2013)

Tabel 5. R-Square

\begin{tabular}{|c|c|}
\hline & $R$-square \\
\hline KDP & 0.188 \\
\hline MKS & 0.756 \\
\hline MP & 0.626 \\
\hline KK & 0.850 \\
\hline KMP & 0.405 \\
\hline
\end{tabular}

Sumber: Output SmartPLS (2013)

Terdapat pengaruh positif signifikan antara dimensi budaya organisasi (instrumen kerja tim/menghormati orang lain) terhadap praktek TQM (Kualiatas Data Pelaporan). Berdasarkan data yang disajikan dalam tabel 5, kerja tim memiliki pengaruh positif terhadap kualitas data pelaporan yang ditunjukkan dengan nilai Original sample estimate sebesar 0.433 dan signifikan yang ditunjukkan dengan nilai t-Statistik 4.114 yang lebih besar daripada t-tabel $(1,96)$. Maka dapat dikatakan Hla diterima yaitu Dimensi budaya organisasi dengan instrumen kerja tim/menghormati orang lain berpengaruh positif dengan tingkat penggunaan praktek TQM (Kualiatas Data Pelaporan).

Terdapat pengaruh positif signifikan antara Dimensi budaya organisasi (instrumen kerja tim/menghormati orang) terhadap praktek TQM (Manajemen Kualitas Suplier). Berdasarkan data Berdasarkan data yang disajikan dalam tabel 5.10 kerja tim memiliki pengaruh positif terhadap manajemen kualitas suplier yang ditunjukkan dengan nilai Original sample estimate sebesar 0.840 dan signifikan yang ditunjukkan dengan nilai t-Statistik 12.274 yang lebih besar daripada t-tabel $(1,96)$. Maka dapat dikatakan H1b diterima yaitu Dimensi budaya organisasi dengan instrumen kerja tim/menghormati orang lain berpengaruh positif dengan tingkat penggunaan praktek TQM (Manajemen Kualitas Suplier).

Terdapat pengaruh positif signifikan antara Dimensi budaya organisasi (instrumen kerja tim/menghormati orang) terhadap praktek TQM (Manajemen Proses). Berdasarkan data Berdasarkan data yang disajikan dalam tabel 5, kerja tim memiliki pengaruh positif terhadap manajemen proses yang ditunjukkan dengan nilai Original 
sample estimate sebesar 0.426 dan signifikan yang ditunjukkan dengan nilai t-Statistik 3.793 yang lebih besar daripada t-tabel $(1,96)$. Maka dapat dikatakan H1c diterima yaitu Dimensi budaya organisasi dengan instrumen kerja tim/menghormati orang lain berpengaruh positif dengan tingkat penggunaan praktek TQM (Manajemen Proses).

Terdapat pengaruh positif signifikan antara Dimensi budaya organisasi (inovasi) terhadap praktek TQM (Manajemen Kualitas Suplier). Berdasarkan data Berdasarkan data yang disajikan dalam tabel 5 , inovasi memiliki pengaruh positif terhadap manajemen kualitas suplier yang ditunjukkan dengan nilai Original sample estimate sebesar 0.047 dan tidak signifikan yang ditunjukkan dengan nilai t-Statistik 0.620 yang lebih kecil daripada t-tabel $(1,96)$. Maka dapat dikatakan $\mathrm{H} 2 \mathrm{a}$ ditolak yaitu Dimensi budaya organisasi dengan instrumen inovasi berpengaruh positif dengan tingkat penggunaan praktek TQM (Manajemen Kualitas Suplier).

Terdapat pengaruh positif signifikan antara Dimensi budaya organisasi (inovasi) terhadap praktek TQM (Manajemen Proses). Berdasarkan data Berdasarkan data yang disajikan dalam tabel 5 , inovasi memiliki pengaruh positif terhadap manajemen proses yang ditunjukkan dengan nilai Original sample estimate sebesar 0.454 dan signifikan yang ditunjukkan dengan nilai t-Statistik 3.954 yang lebih besar daripada t-tabel $(1,96)$. Maka dapat dikatakan $\mathrm{H} 2 \mathrm{~b}$ diterima yaitu Dimensi budaya organisasi dengan instrumen inovasi berpengaruh positif dengan tingkat penggunaan praktek TQM (Manajemen Proses).

Terdapat pengaruh positif signifikan antara manejemen kualitas suplier terhadap kinerja manajemen persediaan. Berdasarkan data Berdasarkan data yang disajikan dalam tabel 5, manajemen kualitas suplier memiliki pengaruh positif terhadap kinerja manajemen persediaan yang ditunjukkan dengan nilai Original sample estimate sebesar 0.751 dan signifikan yang ditunjukkan dengan nilai t-Statistik 9.307 yang lebih besar daripada t-tabel $(1,96)$. Maka dapat dikatakan H3a diterima yaitu manajemen kualitas suplier berpengaruh positif dengan kinerja manajemen persediaan.

Terdapat pengaruh positif signifikan antara manejemen kualitas suplier terhadap kinerja kualitas. Berdasarkan data Berdasarkan data yang disajikan dalam tabel 5 , manajemen kualitas suplier memiliki pengaruh positif terhadap kinerja kualitas yang ditunjukkan dengan nilai Original sample estimate sebesar 0.777 dan signifikan yang ditunjukkan dengan nilai t-Statistik 11.033 yang lebih besar daripada t-tabel $(1,96)$. Maka dapat dikatakan $\mathrm{H} 3 \mathrm{~b}$ diterima yaitu manajemen kualitas suplier berpengaruh positif dengan kinerja kualitas.

Terdapat pengaruh positif signifikan antara manejemen proses terhadap kinerja kualitas. Berdasarkan data Berdasarkan data yang disajikan dalam tabel 5 , manajemen proses memiliki pengaruh positif terhadap kinerja kualitas yang ditunjukkan dengan nilai Original sample estimate sebesar 0.199 dan signifikan yang ditunjukkan dengan nilai tStatistik 3.199 yang lebih besar daripada t-tabel $(1,96)$. Maka dapat dikatakan H4a diterima yaitu manajemen proses berpengaruh positif dengan kinerja kualitas.

Terdapat pengaruh positif signifikan antara manejemen proses terhadap kinerja manajemen persediaan. Berdasarkan data Berdasarkan data yang disajikan dalam tabel 5.10 manajemen proses tidak memiliki pengaruh positif terhadap kinerja manajemen persediaan yang ditunjukkan dengan nilai Original sample estimate sebesar -0.197 dan 
tidak signifikan yang ditunjukkan dengan nilai t-Statistik 1.100 yang lebih kecil daripada t-tabel $(1,96)$. Maka dapat dikatakan $\mathrm{H} 4 \mathrm{~b}$ ditolak yaitu manajemen proses tidak berpengaruh positif dengan manajemen persediaan.

\section{Pembahasan}

Terdapat pengaruh positif signifikan antara dimensi budaya organisasi (instrumen kerja tim/menghormati orang lain) terhadap praktek TQM (Kualiatas Data Pelaporan, Manajemen Kualitas Suplier, Manajemen Proses). Hipotesis Hla, Hlb dan H1c. menyatakan bahwa dimensi budaya organisasi dengan instrumen kerjasama tim / menghormati. orang lain akan berhubungan positif dengan tingkat penggunaan praktek TQM. Pengujian hipotesis yang dilakukannya menerima hipotesis tersebut.

Hasil ini sesuai dengan teori yang dikemukakan Flynn dan Schroeder (1994), kerja sama tim meningkatkan fleksibilitas dan mempersingkat jeda waktu dalam menanggapi variasi dan ketidakpastian dalam proses produksi atau jasa sehingga berkontribusi untuk perbaikan terus menerus dalam proses produksi. Oleh karena itu, organisasi yang mendorong kerja tim / menghormati orang lain diharapkan menggunakan praktek TQM untuk tingkat yang lebih besar, karena kerja sama tim merupakan bagian terpenting dari kesuksesan adopsi dan pelaksanaan TQM.

Terdapat pengaruh positif signifikan antara Dimensi budaya organisasi (inovasi) terhadap praktek TQM (Manajemen Kualitas Suplier). Hipotesis H2a dan H2b. menyatakan bahwa dimensi budaya organisasi dengan instrumen inovasi akan berhubungan positif dengan tingkat penggunaan praktek TQM (Manajemen Kualitas Suplier dan Manajemen Proses). Pengujian hipotesis yang dilakukannya menerima hipotesis tersebut.

Hasil ini sesuai dengan teori yang dikemukakan Juran (1988), perusahaan yang memiliki inovasi akan lebih bersedia untuk bereksperimen dengan praktek-praktek baru seperti praktek TQM. Mereka akan terus mengevaluasi kebutuhan pelanggan dan ekspektasi pasar dalam rangka untuk mengembangkan produk dan layanan baru dan meningkatkan proses produksi saat ini. Oleh karena itu, perusahaan yang lebih berinovasi lebih mungkin untuk mengadopsi dan membuat ekstensif penggunaan praktek TQM.

Hasil ini juga mendukung penelitian sebelumnya Baird et al. (2011) yang menemukan bahwa dimensi budaya organisasi baik itu instrumen kerjasama tim dan juga inovasi keduanya berhubungan positif dengan tingkat penggunaan praktik TQM.

Terdapat pengaruh positif signifikan antara manejemen kualitas suplier terhadap kinerja manajemen persediaan. Hipotesis 3a. menyatakan bahwa manajemen kualitas supplier secara positif terkait dengan kinerja manajemen persediaan. Pengujian hipotesis yang dilakukannya menerima hipotesis tersebut. Hasil ini mendukung penelitian sebelumnya Baird et al. (2011) yang mengatakan bahwa manajemen kualitas supplier memiliki hubungan yang positif dengan kinerja manajemen persediaan.

Terdapat pengaruh positif signifikan antara manejemen kualitas suplier terhadap kinerja kualitas. Hipotesis $\mathrm{H} 3 \mathrm{~b}$. menyatakan bahwa manajemen kualitas supplier secara positif berhubungan dengan kinerja kualitas. Pengujian hipotesis yang dilakukannya mendukung hipotesis tersebut. Bahwa memang benar dengan adanya manajemen kualitas supplier perusahaan memilih supplier dengan teliti sehingga supplier yang berkualitas 
dapat meningkatkan kinerja dari kualitas produk akhir. Akan tetapi, hasil ini berbeda dengan penelitian sebelumnya Baird et al. (2011) yang mengatakan bahwa manajemen kualitas supplier tidak terkait dengan kinerja kualitas.

Terdapat pengaruh positif signifikan antara manejemen proses terhadap kinerja kualitas. Hipotesis 4a. menyatakan bahwa manajemen proses secara positif berhubungan dengan kinerja kualitas. Pengujian hipotesis 4a. dapat diterima.

Hasil ini tidak mendukung penelitian sebelumnya Baird et al. (2011) yang mengatakan bahwa hubungan antara manajemen proses dengan kinerja kualitas tidak signifikan. Hal ini dikarenakan kemungkinan beberapa perusahaan yang diteliti dalam penelitian ini dalam melakukan kebijakan manajemen prosesnya belum bekerja secara efisien. Ketika manajemen proses belum mencapai tingkat efisiensi yang baik, tentunya pengelolaan sumber daya dalam proses produksi dan pengendalian produksi belum dapat bekerja secara efisien pula. Tentunya hal ini akan mempengaruhi kinerja kualitas.

Terdapat pengaruh positif signifikan antara manejemen proses terhadap kinerja manajemen persediaan. Hipotesis $4 \mathrm{~b}$. menyatakan bahwa manajemen proses berpengaruh secara positif terkait dengan kinerja manajemen persediaan. Pengujian hipotesis yang dilakukannya menolak hipotesis tersebut

Hasil ini tidak konsisten dengan penelitian sebelumnya Baird et al. (2011) yang mengatakan bahwa manajemen proses memiliki hubungan yang positif dengan kinerja manajemen persediaan. Hal ini kemugkinan disebabkan oleh beberapa faktor. Yang pertama, perbedaan paling mendasar antara penelitian ini dengan penelitian Baird et al. yaitu terdapat perbedaan pada populasi penelitian. Dalam penelitian ini, populasi yang diambil hanya perusahaan manufaktur yang ada di Banten. Sedangkan Baird et al. melakukan penelitian dengan mengambil populasinya yaitu perusahaan manufaktur dan jasa yang ada di Australia. Yang kedua, dikarenakan kemungkinan beberapa perusahaan yang diteliti dalam penelitian ini dalam melakukan kebijakan manajemen prosesnya belum bekerja secara efisien. Ketika manajemen proses belum mencapai tingkat efisiensi yang baik, tentunya pengelolaan sumber daya dalam proses produksi dan pengendalian produksi belum dapat bekerja secara efisien pula. Tentunya hal ini akan mempengaruhi kinerja dari manajemen persediaan, karena pengendalian produksi termasuk di dalamnya terdapat pengendalian persediaan. Sehingga dalam penelitian ini dapat dikatakan bahwa manajemen proses memiliki hubungan negatif dengan kinerja manajemen persediaan.

\section{PENUTUP}

Kesimpulan. Berdasarkan hasil analisis data, maka dapat ditarik beberapa kesimpulan:

1. Bahwa secara statistik terdapat pengaruh positif signifikan antara dimensi budaya organisasi dengan instrumen kerja tim / menghormati orang lain dengan tingkat penggunaan praktek TQM. ditunjukkan dengan nilai t-Statistik 4.114 yang lebih besar daripada t-tabel $(1,96)$. Maka dapat dikatakan H1a diterima.

2. Berdasarkan statistik kerja tim memiliki pengaruh positif terhadap manajemen kualitas suplier yang ditunjukkan dengan nilai Original sample estimate sebesar 0.840 dan signifikan yang ditunjukkan dengan nilai t-Statistik 12.274 yang lebih besar daripada t-tabel $(1,96)$. Maka dapat dikatakan $\mathrm{H} 1 \mathrm{~b}$ diterima. 
3: Bahwa secara statistik kerja tim memiliki pengaruh positif terhadap manajemen proses yang ditunjukkan dengan nilai Original sample estimate sebesar 0.426 dan signifikan yang ditunjukkan dengan nilai t-Statistik 3.793 yang lebih besar daripada ttabel $(1,96)$. Maka dapat dikatakan H1c diterima.

4. Berdasarkan statistik inovasi memiliki pengaruh positif terhadap manajemen kualitas suplier yang ditunjukkan dengan nilai Original sample estimate sebesar 0.047 dan tidak signifikan yang ditunjukkan dengan nilai t-Statistik 0.620 yang lebih kecil daripada t-tabel $(1,96)$. Maka dapat dikatakan H2a ditolak yaitu Dimensi budaya organisasi dengan instrumen inovasi berpengaruh positif dengan tingkat penggunaan praktek TQM (Manajemen Kualitas Suplier).

5. Secara statistik inovasi memiliki pengaruh positif terhadap manajemen proses yang ditunjukkan dengan nilai Original sample estimate sebesar 0.454 dan signifikan yang ditunjukkan dengan nilai t-Statistik 3.954 yang lebih besar daripada t-tabel $(1,96)$. Maka dapat dikatakan $\mathrm{H} 2 \mathrm{~b}$ diterima yaitu Dimensi budaya organisasi dengan instrumen inovasi berpengaruh positif dengan tingkat penggunaan praktek TQM (Manajemen Proses).

6. Bahwa secara statistik, manajemen kualitas suplier memiliki pengaruh positif terhadap kinerja manajemen persediaan yang ditunjukkan dengan nilai Original sample estimate sebesar 0.751 dan signifikan yang ditunjukkan dengan nilai t-Statistik 9.307 yang lebih besar daripada t-tabel $(1,96)$. Maka dapat dikatakan H3a diterima yaitu manajemen kualitas suplier berpengaruh positif dengan kinerja manajemen persediaan.

7. Berdasarkan data manajemen kualitas suplier memiliki pengaruh positif terhadap kinerja kualitas yang ditunjukkan dengan nilai Original sample estimate sebesar 0.777 dan signifikan yang ditunjukkan dengan nilai t-Statistik 11.033 yang lebih besar daripada t-tabel $(1,96)$. Maka dapat dikatakan $\mathrm{H} 3$ b diterima yaitu manajemen kualitas suplier berpengaruh positif dengan kinerja kualitas.

8. Bahwa secara statistik manajemen proses memiliki pengaruh positif terhadap kinerja kualitas yang ditunjukkan dengan nilai Original sample estimate sebesar 0.199 dan signifikan yang ditunjukkan dengan nilai t-Statistik 3.199 yang lebih besar daripada ttabel $(1,96)$. Maka dapat dikatakan $\mathrm{H} 4$ a diterima yaitu manajemen proses berpengaruh positif dengan kinerja kualitas.

9. Bahwa secara statistik manajemen proses tidak memiliki pengaruh positif terhadap kinerja manajemen persediaan yang ditunjukkan dengan nilai Original sample estimate sebesar -0.197 dan tidak signifikan yang ditunjukkan dengan nilai t-Statistik 1.100 yang lebih kecil daripada t-tabel $(1,96)$. Maka dapat dikatakan $\mathrm{H} 4 \mathrm{~b}$ ditolak yaitu manajemen proses tidak berpengaruh positif dengan manajemen persediaan.

Keterbatasan Penelitian. Adapun keterbatasan-keterbatasan dari penelitian yang telah dilakukan antara lain sebagai berikut:

1. Perusahaan-perusahaan yang dipilih terbatas hanya pada perusahaan-perusahaan manufaktur yang terdapat di Provinsi Banten. Hal ini diakui bahwa tingkat respons dan ukuran sampel kecil, merupakan keterbatasan penelitian ini dan yang terakhir mempengaruhi kekuatan statistik dari analisis yang dilakukan.

2. Secara umum obyek penelitian ini terbatas hanya pada para manajer umum, manajer operasional dan manajer produksi pada perusahaan yang bergerak pada industri manufaktur di Banten. Sebagai akibatnya, kesimpulan dari implikasi praktek TQM yang diperoleh dari penelitian ini mungkin tidak sesuai bila diterapkan pada 
perusahaan-perusahaan selain industri manufaktur karena adanya perbedaan karakteristik budaya organisasi masing-masing perusahaan.

Saran. Berdasarkan kesimpulan yang diperoleh dalam penelitian diatas penulis memberikan saran yaitu: (1) Rekomendasi untuk penelitian yang mendatang adalah untuk memperbesar jumlah populasi responden penelitian tidak hanya pada perusahaan manufaktur saja, tetapi juga perusahaan-perusahaan jasa dan lainnya; (2) Penelitian selanjutnya dapat diperluas dengan menyelidiki hubungan antara dimensi budaya dan keberhasilan praktek TQM.; (3) Untuk penelitian selanjutnya dapat menggunakan metodologi yang berbeda termasuk wawancara, studi lapangan, atau studi kasus longitudinal.

\section{DAFTAR RUJUKAN}

Ahire, S.L. and Dreyfus, P. (2000). The impact of design management and process management on quality: an empirical investigation. Journal of Operations Management, Vol. 18, pp. 549-75.

American Quality Foundation, and Ernst \& Young (1992). The International Quality Study Best Practices Report: An Analysis of Management Practices that Impact Performance, National Association of Accounting, Montvale, NJ.

Baird, K.M., Harrison, G.J. and Reeve, R.C. (2007). The culture of Australian organizations and its relation with strategy. International Journal of Business Studies, Vol. 15 No. 1, pp. 15-41.

Baird, K.M., Jia Hu, K. and Reeve, R.C. (2011). The relationships between organizational culture, total quality management practices and operational performance. International Journal of Operations \& Production Management, Vol. 31 No. 7, pp. 789-814.

Balakrishnan, R., Linsmeier, T.J. and Venkatachalam, M. (1996). Financial benefits from JIT adoption: effects of customer concentration and cost structure. The Accounting Review, Vol. 71 No. 2, pp. 183-205.

Ciptani, Monika Kussetya. (1999). Pengukuran Biaya Kualitas: Suatu Paradigma Alternatif. Jurnal Akuntansi dan Keuangan Vol. 1, No. 1: $68-83$.

Flynn, B.B., Schroeder,R.G. and Sakakibara, S. (1995). The impact of qualitymanagement practices on performance and competitive advantage, Decision Sciences, Vol. 26, pp. 659-91.

Forza, C. and Filippini, R. (1998). TQM impact on quality conformance and customer satisfaction: a causal model. International Journal of Production Economics, Vol. 5 Ș No. 1, pp. 1-20.

Gotzamani, K.D. and Tsiotras, G.D. (2001). An empirical study of the ISO9000 standards' contribution towards total quality management. International Journal of Operations \& Production Management, Vol. 21 No. 10, pp. 1326-42.

Gozhali, I. (2008). Model Persamaan Struktural Konsep dan Aplikasi Dengan Program Partial Least Square (PLS). Semarang. Badan Penerbit Universitas Diponegoro.

Handfield, R., Ghosh, S. and Fawcett, S. (1998). Quality-driven changes and its effects on financial performance, Quality Management Journal, Vol. 5 No. 3, pp. 13-30. 
Ho, D.C.K., Duffy, V.G. and Shih, H.M. (1999). An empirícal analysis of effective TQM implementation in the Hong Kong electronics manufacturing industry, Human Factors and Ergonomics in Manufacturing, Vol. 9 No. 1, pp. 1-25.

Hofstede, G., Neuijen, B., Ohayv, D.D. and Sanders, G. (1990). Measuring organizational cultures: a qualitative and quantitative study across twenty cases. Administrative Science Quarterly, June, pp. 286-316.

Juran, J.M. (1988). Juran's Quality Control Handbook, McGraw-Hill, New York, NY.

Kaynak, H. (2003). The relationship between total quality management practices and their effects on firm performance. Journal of Operations Management, Vol. 21, pp. 40535 .

Kiella, M.L. and Golhar, D.Y. (1997). Total quality management in an R\&D environment. International Journal of Operations \& Production Management, Vol. 17 No. 2, pp. 184-98.

Krajewski, L.J. and Ritzman, L.P. (2001). Operations Management: Strategy and Analysis, 6th ed., Prentice-Hall, Upper Saddle River, NJ.

Mahoney, T. A., Jerde, T. H., \& Carroll, S. J. (1963). Development of managerial performance: a research approach. Cincinnati: South-Western.

Malahayati, Anastasia. (2010). Implementasi Adopsi Total Quality Management (TQM) Terhadap Budaya Kualitas (Studi pada PT. Aryan Indonesia/Kidzania Jakarta). Tesis S2 Universitas Pembangunan Nasional "Veteran". Jakarta.

O'Reilly, C.A., Chatman, J. and Caldwell, D.F. (1991). People and organizational culture: a profile comparison approach to assessing person-organizational fit. Academy of Management Journal, Vol. 34 No. 3, pp. 487-516.

Powell, T.C. (1995). Total quality management as competitive advantage: a review and empirical study. Strategic Management Journal, Vol. 16, pp. 15-37.

Prajogo, D.I. and McDermott, C.M. (2005). The relationship between total quality management practices and organizational culture. International Journal of Operations \& Production Management, Vol. 25 No. 11, pp. 1101-22.

Saraph, J.V., Benson, P.G. and Schroder, R.G. (1989). An instrument for measuring the critical factors of quality, Decision Sciences, Vol. 20 No. 4, pp. 810-29.

Schein, E. (1985). Organizational Culture and Leadership, Jossey-Bass, San Francisco, CA.

Soltani, E., Van Der Meer, R. and Williams, T. (2005). A Contrast of HRM and TQM Approaches to Performance Management: Some Evidence, British Journal of Management, Vol. 16, pp. 211-30.

US Department of Commerce (1994). Malcolm Baldrige National Quality Award, Department of Commerce, Gaithersburg, MD.

Wicaksono, Setiawan. (2006). Pengaruh Implementasi Total Quality Management (TQM) Terhadap Budaya Kualitas (Studi pada PT. Hari Terang Industry - Surabaya). Tesis S2 Universitas Brawijaya. Malang.

Windsor, C.A. and Ashkanasy, N.M. (1996). Auditor independence decision making: the role of organization culture perceptions, Behavioral Research in Accounting, Vol. 8 , pp. 80-97. 